\title{
Low-dose Radiation Treatment for Painful Heel Spur: a Highly Effective Therapy With Little Side Effects
}

\section{Freddy-Joel Djiepmo Njanang}

Heinrich Heine University Düsseldorf: Heinrich-Heine-Universitat Dusseldorf

\section{Balint Tamaskovics}

Heinrich Heine University Düsseldorf: Heinrich-Heine-Universitat Dusseldorf

Edwin Boelke ( $\sim$ boelke@med.uni-duesseldorf.de)

Heinrich-Heine-Universitat Dusseldorf https://orcid.org/0000-0001-9112-1024

\section{Matthias Peiper}

Heinrich Heine University Düsseldorf: Heinrich-Heine-Universitat Dusseldorf

\section{Jan Haussmann}

Heinrich Heine University Düsseldorf: Heinrich-Heine-Universitat Dusseldorf

Judith Neuwahl

Heinrich Heine University Düsseldorf: Heinrich-Heine-Universitat Dusseldorf

\section{Danny Jazmati}

Heinrich Heine University Düsseldorf: Heinrich-Heine-Universitat Dusseldorf

\section{Kitti Maas}

Heinrich Heine University Düsseldorf: Heinrich-Heine-Universitat Dusseldorf

\section{Livia Schmidt}

Heinrich Heine University Düsseldorf: Heinrich-Heine-Universitat Dusseldorf

\section{Romans Gelzhaeusser}

Heinrich Heine University Düsseldorf: Heinrich-Heine-Universitat Dusseldorf

\section{Christiph Schleich}

Heinrich Heine University Düsseldorf: Heinrich-Heine-Universitat Dusseldorf

\section{Klaus Orth}

Heinrich Heine University Düsseldorf: Heinrich-Heine-Universitat Dusseldorf

\section{Stefanie Corradini}

Heinrich Heine University Düsseldorf: Heinrich-Heine-Universitat Dusseldorf

\section{Martijn van Griensven}

Heinrich Heine University Düsseldorf: Heinrich-Heine-Universitat Dusseldorf

\section{Amir Rezazadeh}

Heinrich Heine University Düsseldorf: Heinrich-Heine-Universitat Dusseldorf 
Heinrich Heine University Düsseldorf: Heinrich-Heine-Universitat Dusseldorf

\section{Wilfried Budach}

Heinrich Heine University Düsseldorf: Heinrich-Heine-Universitat Dusseldorf

\section{Christiane Matuschek}

Heinrich Heine University Düsseldorf: Heinrich-Heine-Universitat Dusseldorf

\section{Research}

Keywords: heel spur, radiation therapy, benign disease, pain, photon therapy, electrons

Posted Date: September 3rd, 2021

DOI: https://doi.org/10.21203/rs.3.rs-820240/v1

License: (c) (1) This work is licensed under a Creative Commons Attribution 4.0 International License. Read Full License 


\section{Abstract}

Aim: Evaluation of pain reduction using orthovolt or cobalt-based radiation treatment for painful heel spurs and determination of long-term response as well as prognostic parameters.

Methods: We identified a total of 102 consecutive patients treated for a total of 117 symptomatic heel spurs. 59 patients were treated with cobalt radiation, 31 patients with orthovolt therapy and 12 patients with both radiation systems. Pain reduction was scored using the modified Rowe-Score prior therapy, at the end of each treatment series as well as after 6 weeks and at the time of data collection. Long-term outcome was evaluated in patients with a follow-up period of longer than three years.

Results: Before radiation therapy, 61 patients $(60.4 \%)$ had a score of 0 , significant strong pain. At the time of completion of radiation treatment, 3 patients $(2.7 \%)$ were pain free (score of 30 ), whereas 8 patients (7.9\%) had still severe pain (score 0$) .6$ weeks after radiation therapy, 33 patients $(32.7 \%)$ were pain-free and 8 patients $(7.9 \%)$ had severe pain (score 0$)$, while at the time data of collection, 74 patients $(73 \%)$ were free of pain and 1 patient (1\%) had strong pain (score 0 ). Duration of pain before the start of radiation treatment was a significant prognostic factor $(p=0.012)$ for response to treatment. Hier noch etwas über die Nebenwirkungen schreiben? Darauf gehen wir in der Conclusion ja ein.

Conclusion: Radiotherapy of painful heel spurs is a highly effective therapy with little side effects providing long-term therapeutic response. The only significant prognostic parameter for response to treatment is the duration of pre-radiation therapy pain. Early integration of radiation therapy in the treatment seems to result in superior pain reduction.

\section{Introduction}

Heel spur is a painful degenerative disorder evolving over a long time ${ }^{1-4}$ and is localized at the tuber calcanei ${ }^{5}$ (Fig. 1).

Heel spur was first described by Plettner ${ }^{6}$. He investigated radiological findings of exostosis at the plantar sole and parts of the calcaneus. Nowadays, heel spurs are one of the most common causes of pain in the heel region.

The heel spur develops as a reactive formation of bone due to mechanical stress with degenerative changes and microtraumas at the insertion of the tendons of the abductor hallucis and the brevis flexor digitorum muscles as well as the plantar aponeurosis and can therefore be identified as a result of a plantar fasciitis. Nevertheless, this term is misnomer, since the plantar fascia is an aponeurotic rather than a fascial layer. Heel spurs are located at the calcaneus where the plantar aponeurosis inserts at the medial tuber calcanei or at the insertion of the Achilles tendon in a dorsal position. Combinations of the two locations have also been described ${ }^{7}$. Risk factors are female sex (Female: male $\left.=3: 1\right)^{8}$, age above 40 years, obesity, weight bearing occupation ${ }^{9}$ as well as anatomical deformity of the foot such as talipes valgus, talipes planus and flatfoot ${ }^{7}$. 
The majority of patients with heel spur remain asymptomatic. If clinically apparent, typical symptoms are pressure pain at the medial part of the arch of the foot radiating to the calf and the sole of the foot. The pain is often described as burning or stinging, emerging while walking barefoot or after resting. Therefore, the diagnosis of plantar fasciitis is mostly a clinical one. Any further diagnostic approach should be tailored according to the clinical picture and includes foremost plain $\mathrm{x}$-ray. Additional diagnostical regimen may include technetium bone scintigraphy (revealing a fasciitis) as well as MRI, though both techniques are rarely used.

Usually, there physical activity may improve clinical symptoms, though long exercise may result in worsening. This results in a relieving posture of the heel with limping on the football ${ }^{10-14}$. Conservative or invasive therapeutic options have been implemented in the therapy of heel spurs. Primary treatment usually consists of conservative management including orthotics, local or systemic analgesics, corticosteroids $^{15}$, antiphlogistics ${ }^{16,17}$, physiotherapy ${ }^{10}$ and stretching exercises ${ }^{18,19}$. Massages, local thermotherapy, ultrasound and electrical stimulation therapy are often prescribed several times ${ }^{20,21}$. Nafe and other authors were able to demonstrate a temporary pain reduction effect of extracorporeal shockwave therapy ${ }^{3,4,22-26}$. However, at least in Germany, the latter therapeutical approach is rarely compensated by health insurances. Despite high rates of recurrences, surgical management was used for chronic pain condition after conservative therapy but is usually not a standard method in the treatment of a painful heel spur ${ }^{1,15,27,28}$. Despite an increasing number of physicians successfully using radiation treatment in degenerative inflammatory disorders, the role of radiotherapy in this context is currently under discussion ${ }^{29-31}$.

In this retrospective study we tried to clarify the following questions:

Which parameters influence the clinical outcome (pain reduction) in the radiation treatment of heel spurs? We identified radiation parameters (single fraction and overall fraction dose, overall treatment time, field size (radiologically vs. clinically guided fields), type of radiation) as well as clinical parameters (sex, age, treatment prior to radiation, duration of pain prior to radiation).

\section{Patients And Methods}

During two years, 102 patients were treated for overall 117 heel spurs. 28 male (27.2\%) und 74 female (71.8\%) patients with a mean age of 51,5 years (range: $20-80$ years, median 52 years) were included in this study. 87 patients had a one-sided heel spur (55 right, 32 left) and 15 patients had bilateral heel spurs. The correct diagnoses was confirmed using X-rax by two radiologists. Patients were treated with cobalt radiation $(60 \mathrm{Co})$ and 31 with $\mathrm{x}$-rays with an orthovoltage irradiation $(300 \mathrm{kV}) .12$ patients were treated with both energies.

Radiation treatment was indicated in patients aged 20 to 50 years when conservative methods failed to reduce clinically evident pain and patients experienced a loss of function in everyday life. 
Radiation treatment with both techniques consisted of 6 fractions of 0.5-1 (Gray) Gy given 2-3 times a week up to total dose of 3 or $6 \mathrm{~Gy}$. In detail, patients being treated with cobalt radiation were irradiated 3 times a week with a dose/ fraction of 0.5 or $1 \mathrm{~Gy}$ up to a total dose of 3 or $6 \mathrm{~Gy}$, depending on their pain intensity. Higher doses of radiation were prescribed for patients with persistent and severe pain. They always received a total of 6 fractions. Orthovoltage irradiation was applied 2 to 3 times per week with a dose/ fraction of $1 \mathrm{~Gy}$ and a total dose of 3 or $6 \mathrm{~Gy}$, resulting in a total of 3 or 6 fractions were applied. In addition, the therapeutic effect of local steroid injection was evaluated.

If only temporary or partial pain relief was obtained, a second course was offered to the patients. This was given after a median time gap of 5.4 (range $x x-x x)$ months after initial treatment.

Pain and function were evaluated using a modified score of Rowe et $\mathrm{al}^{32}$. Table 1 shows the criteria used in this measurement. Patients were contacted directly or interviewed by telephone and completed the questionnaire retrospectively for the following four points in time: (1) before start of radiation, (2) on the last day of radiation, (3) 6 weeks after radiation, (4) during follow-up (at least 3 years after radiation treatment).

We statistically evaluated radiation-associated factors (single and overall dose, treatment time, field size, type of radiation, pain medication) and clinical parameters (sex, age, prior treatment before radiation, duration of pain before radiation treatment) possibly influencing the clinical outcome using MicrosoftExcel 2010 and SPSS-20.

Data were expressed at mean \pm standard error of the mean (SEM). Statistical significance was assessed by Mann-Whitney $U$ and $t$-test. P-values less than or equal to 0.05 were considered statistically significant $\left({ }^{*} p \leq 0.05,{ }^{*} p \leq 0.01,{ }^{* *} p \leq 0.001\right)$. With the Kruskal-Wallis test, we examined the influence of radiotherapy on pain relief in different groups 
Table 1

Modified pain and function score according to Rowe et al.

criteria

Response Level

Score

1. pain

Pain

None

30

at rest

Mild

20

Moderate

10

Severe

0

Pain in motion

None

Mild

20

Moderate

10

Severe

0

Pain when applying pressure to the heel

None

Mild

20

Moderate

Severe

0

2.medical aids

None

Orthopedic insoles, sole padding

One walking aid (cane or forearm support)

5

two walking aids

0

3. everyday activities

normal, no constraints

small constraints

10

moderate constraints

complete constraints

0

4. Gait

no limping, normal gait with no constraints 20

mild pain and limping after $>1 \mathrm{~km}$

moderate pain and limping after $<1 \mathrm{~km}$

5

severe pain, no normal gait possible

0

Score 120-140: excellent; Score 90-120: good;

Score 60-90: moderate; Score 30-60 mild; Score 0-30 severe 


\section{Results}

Table 2 shows our patients characteristics. 102 patients were treated for a number of 117 symptomatic heel spurs. 59 patients were treated with 60-cobalt therapy, 31 patients with orthovolt therapy and 12 patients with both radiation systems.

Table 2

Patients characteristics

\begin{tabular}{|lll|}
\hline Criteria & N` of patients & (\%) \\
\hline Patients & 102 & 100 \\
\hline Female & 74 & 71,8 \\
\hline Male & 28 & 27,2 \\
\hline Spurs & 117 & 100 \\
\hline Right-sided & 55 & 54,1 \\
\hline Left-sided & 32 & 31,6 \\
\hline Bilateral & 15 & 14,3 \\
\hline Pre-treatment & 134 & 100 \\
\hline Orthopedic insoles & 48 & 35,8 \\
\hline Corticoid infiltrations & 25 & 18,6 \\
\hline Antiphlogistics (oral) & 34 & 25,3 \\
\hline Physiotherapy & 3 & 2,2 \\
\hline Shockwave therapy & 6 & 4,5 \\
\hline Massage & 5 & 3,7 \\
\hline Ultrasound therapy & 4 & 2,9 \\
\hline Antiphlogistics (ointment) & 5 & 3,7 \\
\hline Corticosteroids (Oral) & 2 & 1,5 \\
\hline Operative therapy & 2 & 1,5 \\
\hline
\end{tabular}

Prior to RT treatment, 100 patients (99\%) presented with a Rowe S-Score between 0-30 (severe pain) and only 1 patient (1\%) had a S-Score between 30-60 (mild pain) (Fig. 2).

On the last day of RT treatment, 21 patients $(20.8 \%$ ) achieved a S-Score between $0-30$ (mild to no improvement), 26 patients (25.7\%) a S-Score between 30-60 (mild pain improvement), 24 patients 
(23.7\%) a S-Score between 60-90 (mild to moderate improvement) and 29 patients ( $28.7 \%$ ) had a SScore between 90-120 (good pain response). Only 1 patient (1\%) achieved a complete pain response with a S-Score between 120-150.

If patients were contacted directly or interviewed by telephone and completed the questionnaire retrospectively for 6 weeks after radiation, during follow-up (at least 3 years after radiation treatment) 53 patients (52.5\%) had a S-Score of 0-30 (mild to no improvement of pain), 2 patients ( $2 \%$ ) a S-Score between 30 and 60 (mild improvement of pain), 7 patients (6.9\%) a S-Score of $60-90$ (mild to moderate improvement of pain) and 6 patients (5.9\%) had an S-Score of 90-120 (major improvement of pain). Overall, 33 patients (32.7\%) had a complete pain remission with a S-Score of 120-150.

At the time of data collection, the results of a telephone questionnaire were the following: 19 patients (18.8\%) reported a S-Score of $0-30,2$ patients (2\%) a S-Score between 60 and 90,7 patients $(6.9 \%)$ a SScore of $90-120$ and 73 patients $(72.3 \%)$ had a S-Score of $120-150$. No patient reported a S-Score of 60 - 40 and 14 patients (13.9\%) expirienced a S-Score of 0.

As presented in Fig. 3 the best results were achieved 6 weeks after radiation therapy and if the radiation field was large.

Figure 4 shows the summary of the bootstrap confidence intervals of radiation results using the modified Rowe-Scores on the last day of RT, 6 weeks after RT and at data collection. Also, this investigation shows that the best results were achieved 6 weeks after RT.

The long-term response was evaluated in 102 patients after a median follow-up period of 94.4 months (range: $36-187$ months). 16 patients received 2 irradiation series (4 patients received orthovoltage radiotherapy, 9 patients irradiation using cobalt and 3 patients both). Furthermore, the influence of different parameters (radiotherapeutic and clinical) on the therapeutic response (pain-reduction) of the irradiation of heel sporns was evaluated. There were no significant differences between the groups receiving different single doses at any time point (p-value: on the last day of RT: 0.922, 6 weeks after RT: 0.865, at data collection: 0.949). Similarly, no significant differences following the Pearson-correlation could be identified between the total dose ( 3 or $6 \mathrm{~Gy}$ ) and the therapeutic results according to the RoweScores on the last day of irradiation $(r=-0.157, p=0.172), 6$ weeks after completion of radiotherapy $(r=$ $0.013, p=0.905)$ and at data collection $(r=-0.061, p=0.670)$. Moreover, no significant influence of the total treatment time on any outcome were detected using the Pearson-correlation: on the last day of radiotherapy $(r=0.06, p=0.5), 6$ weeks after irradiation $(r=0.022, p=0.87)$ and at data collection $(r=-0.12$, $p=0.27)$.

Regarding the size of the radiation fields, there was a significant influence $(p=0.011, r=-0.0282)$ of the field size on the clinical outcome at 6 weeks after irradiation. This indicates a better effect of radiotherapy when an extended field was used, to irradiate the complete pain expansion on the heel. Nevertheless, this effect did not influence the early outcome on the last day of irradiation $(r=-0.052, p=$ $0.657)$ and the late outcome at data collection $(r=-0.036, p=0.806)$. A pretreatment of patients with oral 
NSAIDs had a significant effect $(\mathrm{p}=0.047) 6$ weeks after completion of radiotherapy. While patients who did not receive NSAIDs $(n=23)$ had an average score of $65.22(S D=29.52)$, patients undergoing NSAIDtherapy $(n=32)$ achieved an average Score of $51.25(S D=24.05)$. This indicates that pretreated patients who continued NSAID-therapy experienced a lesser pain-improvement than patients receiving radiotherapy without NSAIDs. This effect was not significant at long-term follow up.

Though not performed via randomization, we analyzed any effect of local steroid injection on therapeutic outcome. We identified a significant lapse of pain reduction when local corticosteroid-injection on the last day of radiotherapy was administered $(p=0.036) .31$ patients without prior corticoid-therapy had an average score of $34.19(S D=16.6)$ compared to 24 patients who had received corticoid-injections reported an average score of $23.7(S D=20.6)$. This significant difference may indicate that patients receiving local infiltrations on the last day of radiotherapy experienced less pain reduction than patients without corticoid-therapy. It could also be that these patients have a more persistent heel spur and that there has been no improvement even after many pre-therapies. This significance was also observed 6 weeks after radiotherapy as well $(p=0.001)$, while it was not significantly different at long-term outcome $(p>=0.05)$.

There was no significant impact of the age of the patients on the therapy outcome on the last day of radiotherapy $(r=0.17, p=0.12)$ and at long-term follow-up $(r=0.078, p=0.49)$. Nevertheless, there was a significant influence of the patients' age on the therapeutic results 6 weeks after radiotherapy $(r=0.28, p$ $=0.041)$. Higher age was significantly associated with improved outcome 6 weeks after irradiation.

Using the Mann-Whitney-U-Test, we were able to demonstrate that neither the patients' gender, nor the technique used for radiotherapy did influence the outcome at any time. The symptomatic time before the beginning of radiotherapy showed a significant correlation on long-term outcome $(p=0.012, r=0.315)$. Patients receiving irradiation a few months after the onset of heel spur pain benefited significantly more from radiotherapy and experienced a higher pain remission than patients with delayed irradiation.

In the present study, we have categorized pain into functional scores. The pain was subdivided into pain at rest, pain at motion and pressure pain. Overall, 33 patients (32.7\%) reported a complete pain regression six weeks after RT. After a follow-up of 94.4 months (range: 36-187 months), 74 patients (73\%) achieved a complete response. These results confirm the effectivity of this treatment approach. The analysis of functional scores revealed that $85.5 \%$ of the patients had none or only minor restrictions in daily activities and $89 \%$ had a normal gait pattern.

\section{Discussion}

Degenerative and inflammatory diseases of the musculoskeletal system make up $70 \%$ of all benign diseases treated by irradiation 3,5,6,13,26,33-43. In Germany, more than 3500 patients annually are treated with this disease ${ }^{44}$. The use of low-dose irradiation when treating degenerative and inflammatory diseases has a long tradition in middle-European countries, especially in Germany ${ }^{44-48}$. 
Low-dose radiation decreases the expression and activity of glutathione peroxidase (Gpx) and nuclear factor erythroid 2-related factor 2 (Nrf2) in endothelial cells. The adhesion of peripheral blood mononulcear cells is also reduced. Large et al. provided evidence for an anti-inflammatory effect in endothelial cells stimulated by inflammation after low-dose radiation (largest effect after irradiation using $0.5 \mathrm{~Gy})^{49}$.

Historically, heel spurs were treated surgically in most symptomatic patients. Since surgery carries a high risk of recurrence, it is rarely performed today. Moreover, the treatment focus on symptomatic $t$ pain relief. Physiotherapy, footbed insert and medical treatment using NSAID is associated with a high therapeutic failure rate. Multiple studies in German-speaking countries reported the benefits of radiation treatment in the treatment of heel spurs in the past ${ }^{6,26,29-31,44,46,47,50-59}$.

Table 3 shows the results of 19 publications between 1924 and 2004 with a total number of 3325 cases. Radiation concepts included multiple dose schemes and radiation qualities. On average, a complete pain response was achieved in $55.8 \%$ of the cases. Partial pain responses were reported in $31.2 \%$, while $13.0 \%$ had no improvement after radiation therapy. Overall response rates varied between $65 \%$ and $100 \%$ (Mean: $87.6 \%$ ). 
Table 3

Summary of previous published studies. CR: complete remission, ED: single dose, GD: total dose, NR: no remission, PR: partial remission

\begin{tabular}{|c|c|c|c|c|c|c|c|}
\hline publication & Patients & Dose (Gy) & technique & response- & CR & PR & NR \\
\hline & $\mathrm{n}$ & $E D / G D$ & & rate (\%) & $(\%)$ & $(\%)$ & (\%) \\
\hline Richarz (1924) 60 & 5 & & Orthovolt & 100 & 80 & 20 & 0 \\
\hline Pannewitz (1933) 61 & 88 & & Orthovolt & & & & \\
\hline $\begin{array}{l}\text { Mustakallio \& } \\
\text { Laitinien (1939) } 62\end{array}$ & 17 & $\begin{array}{l}1,0- \\
1,5 / 4,0-6,0\end{array}$ & Orthovolt & 82 & 76 & 6 & 18 \\
\hline Cocchi (1943) ${ }^{63}$ & 6 & $1,8 / 9,0$ & Orthovolt & 83 & 33 & 50 & 17 \\
\hline Pizon (1957) ${ }^{64}$ & 3 & & Orthovolt & 100 & 100 & 0 & 0 \\
\hline $\begin{array}{l}\text { Wieland \& Kuttig } \\
\text { (1965) } 65\end{array}$ & 16 & $1,0 / 4,0$ & Cobalt-60 & 100 & 74 & 13 & 13 \\
\hline $\begin{array}{l}\text { Mitrov \& Harbov } \\
(1967)^{66}\end{array}$ & 1520 & $\begin{array}{l}0,5- \\
1,5 / 3,0-9,0\end{array}$ & Orthovolt & 88 & 50 & 38 & 12 \\
\hline Zschache (1972) 67 & 49 & $\begin{array}{l}0,74- \\
1,5 / 2,25- \\
4,5\end{array}$ & Orthovolt & 86 & 12 & 74 & 14 \\
\hline Mantell (1978) 68 & 26 & $2,0 / 10,0$ & $240-300 \mathrm{KV}$ & 65 & 53 & 12 & 35 \\
\hline $\begin{array}{l}\text { Basche et al. (1980) } \\
69\end{array}$ & 102 & $0,3-0,5 / 4,0$ & $120 \mathrm{Kv}$ & 90 & 32 & 58 & 10 \\
\hline $\begin{array}{l}\text { Sautter-Bihl et al. } \\
(1993)^{70}\end{array}$ & 15 & $\begin{array}{l}0,5- \\
1,0 / 2,5-6,0\end{array}$ & Cobalt-60 & 80 & 60 & 20 & 20 \\
\hline $\begin{array}{l}\text { Schäfer et al. (1995) } \\
71\end{array}$ & 11 & $\begin{array}{l}0,5- \\
1,0 / 2,0-4,0\end{array}$ & Cobalt- 60 & 72 & 13 & 59 & 27 \\
\hline \multirow{2}{*}{$\begin{array}{l}\text { Seegenschmiedt et al. } \\
\text { (1996) }{ }^{72}\end{array}$} & 72 & $1,0 / 12,0$ & $250 \mathrm{Kv}$ & 100 & 67 & 33 & 0 \\
\hline & 98 & $\begin{array}{l}0,3- \\
0,5 / 3,0-5,0\end{array}$ & $200 \mathrm{Kv}$ & 95 & 72 & 23 & 5 \\
\hline $\begin{array}{l}\text { Lederer et al. (1998) } \\
73\end{array}$ & 21 & $1,0 / 6,0$ & $\begin{array}{l}\text { 4-6 MV, } \\
\text { Cobalt-60 }\end{array}$ & 91 & 43 & 48 & 9 \\
\hline $\begin{array}{l}\text { Oehler \& Hentschel } \\
(2000){ }^{74}\end{array}$ & 258 & & Orthovolt & 88 & 81 & 7 & 12 \\
\hline
\end{tabular}




\begin{tabular}{|c|c|c|c|c|c|c|c|}
\hline publication & Patients & Dose (Gy) & technique & response- & CR & PR & NR \\
\hline & $\mathbf{n}$ & $E D / G D$ & & rate $(\%)$ & $(\%)$ & $(\%)$ & $(\%)$ \\
\hline $\begin{array}{l}\text { Koeppen et al. (2000) } \\
75\end{array}$ & 673 & $0,3 / 1,5-3,0$ & $250 \mathrm{Kv}$ & 78 & 13 & 65 & 22 \\
\hline $\begin{array}{l}\text { Schreiber et al. (2000) } \\
76\end{array}$ & 87 & $1,0 / 6,0$ & $6 \mathrm{MV}$ & 86 & 67 & 19 & 14 \\
\hline Heyd et al. (2001) ${ }^{77}$ & 105 & & $6 \mathrm{MV}$ & 88 & 46 & 42 & 12 \\
\hline Glatzel et al. (2001) 78 & 161 & $\begin{array}{l}1,0 / 6,0- \\
12,0\end{array}$ & $175 \mathrm{Kv}$ & 89 & 63 & 26 & 11 \\
\hline Mücke et al. (2003) 79 & 117 & $0,5 / 5,0-1,0$ & $6 \mathrm{MV}$ & 89 & 73 & 16 & 11 \\
\hline $\begin{array}{l}\text { Schneider et al. } \\
(2004)^{80}\end{array}$ & 68 & $\begin{array}{l}0,25- \\
1,0 / 5,0\end{array}$ & $10 \mathrm{MV}$ & 90 & 53 & 37 & 10 \\
\hline Heyd et al. (2006) ${ }^{81}$ & 252 & $1,0 / 6,0$ & $6 \mathrm{MV}$ & 85,6 & 44,3 & 19,7 & 15,4 \\
\hline Heyd et al. (2007) ${ }^{82}$ & 130 & $\begin{array}{l}0,5- \\
1,0 / 3,0-6,0\end{array}$ & $6 \mathrm{MV}$ & 87,7 & & & 12,3 \\
\hline $\begin{array}{l}\text { Niewald et al. (2012) } \\
83\end{array}$ & 66 & $\begin{array}{l}1,0- \\
0,1 / 6,0-0,6\end{array}$ & $6 \mathrm{MV}$ & & & & \\
\hline
\end{tabular}

Despite comprehensive clinical results, the optimal radiation dose concept needs yet to be identified. In the pattern-of-care study by Micke and Seegenschmiedt ${ }^{44}$, single doses varied from 0.3 to $1.5 \mathrm{~Gy}$ and total doses from 2.5 to $18.75 \mathrm{~Gy}$. In most institutions, two (44\%) to three $(37.5 \%)$ weekly fractions of 0.5 to $1.5 \mathrm{~Gy}$ were utilized. However, the authors failed to demonstrate a dose relationship. Seegenschmiedt et al. ${ }^{6}$ identified in his study the best response rates if patients received $5 \mathrm{~Gy}$ or $12 \mathrm{~Gy}$ total dose, while patients with only 3 Gy total dose had significantly worse outcome.

Heyd et al. recently published a prospective, randomized study comparing the effect of $3 \mathrm{~Gy}$ ( 6 fractions of $0.5 \mathrm{~Gy}$ ) vs. $6 \mathrm{~Gy}$ ( 6 fractions of $1 \mathrm{~Gy}$ ). Both groups demonstrated a significant improvement of symptoms. A different effect of the applied radiation dose was not reported.

Our study identified size of the radiation field as a significant factor for the treatment response 6 weeks after radiation $(p=0.011)$. At the time of long-term follow-up, this effect could no longer be demonstrated. Comparable results had not been reported previously.

Previous treatments with NSAID or local steroid injections had a detrimental effect on the response to therapy. NSAID-pretreated patients had a reduced pain response at 6 weeks after RT and corticoid 
injections led to a worse response at the last day of RT and 6 weeks hereafter. We were unable to obtain any comparable data from the literature.

Statistical analysis provided evidence that a short pretherapeutic pain duration ${ }^{6,26,30,57,84}$ and an increased patients` age ${ }^{6,30,57}$ were prognostic factors for improved outcome. Glatzel and coauthors reported an improved outcome when pain duration was below 12 months or the patient's age above 50 years ${ }^{30}$. Similarly, Mücke $\mathrm{e}^{46}$ and Schneider ${ }^{57}$ also reported a significantly better pain response with a pretherapeutic pain duration of $<6$ months $^{84}$.

Acute and late side effects of radiation treatment have not been studied in the present population. Some authors describe an initial pain exacerbation probably due to a probably localized acidotic tissue reaction ${ }^{85}$.

This study is limited by the retrospective study design. Furthermore, the investigated cohorts were irradiated with different concepts and techniques, which strongly reduces the validity of this study.

Furthermore, in consideration of the benign condition, the length of the follow-up is not sufficient for a conclusive evaluation concerning the role of radiotherapy. Nevertheless, this study represents real-life data from a large cohort of patients with high levels of pain from a disease that has not been sufficiently investigated by large prospective trials, providing results to help inform radiotherapy decision-making.

\section{Conclusion}

In addition to conservative treatment using physiotherapy, lifestyle changes, oral medication and orthopedic devices, radiotherapy can be regarded as a treatment option for painful heel spur. Low radiation doses lead to a significant long-term pain-reduction in more than $60 \%$ of the treated patients. In accordance with previous publications ${ }^{26,30,46,57,86}$ we found that pretreatment pain duration was a significant prognostic factor for treatment response. In future prospective studies further associated parameters should be evaluated. In order to better assess the role of radiotherapy prospective studies or analyses with a longer follow-up would be desirable.

\section{Abbreviations}

Co: Cobalt

Gy: Gray

NSAID: Non-steroidal anti-inflammatory drugs

$\mathrm{RT}$ : radiotherapy

SD: standard deviation 


\section{Declarations}

\section{Authors' contribution}

$F D, E B, J H, J N, K M, R G, C S, B T, S C, K O, M v G, K K, A R, W B, C M$ wrote parts of the manuscript. FD and BT did the literature research and prepared the data for analysis. $\mathrm{FD}, \mathrm{CM}, \mathrm{BT}, \mathrm{EB}$ and $\mathrm{JH}$ contributed significantly to the discussion on the interpretation of the results. All authors read and approved the final manuscript.

\section{Competing interests}

All authors including the corresponding author declare that they have no competing interests.

Martijn van Griensven is the chief editor of the European Journal of Medical Research. Edwin Bölke is a section editor of the European Journal of Medical Research. Christiane Matuschek is an associate editor of the European Journal of Medical Research.

\section{Availability of data and materials}

All data and materials can be accessed via CM and FD.

\section{Consent for publication}

All authors gave consent for the publication

\section{Ethics approval and consent to participate}

The study was approved by the local ethical commission board.

\section{Funding}

There was no funding for this investigation.

\section{Acknowledgment}

This work is dedicated to Gerd Schmitt

\section{References}

1. Boike AM, Snyder AJ, Roberto PD, Tabbert WG. Heel spur surgery. A transverse plantar approach. J Am Podiatr Med Assoc 1993;83:39-42.

2. Prichasuk S. The heel pad in plantar heel pain. J Bone Joint Surg Br 1994;76:140-2.

3. Sistermann R, Katthagen B-D. 5 Jahre Lithotripsie des plantaren Fersenspornes: Erfahrungen und Ergebnisse-eine Nachuntersuchung nach 36, 9 Monaten. Zeitschrift für Orthopädie und ihre 
Grenzgebiete 1998;136:402-6.

4. Weil LS, Jr., Roukis TS, Weil LS, Borrelli AH. Extracorporeal shock wave therapy for the treatment of chronic plantar fasciitis: indications, protocol, intermediate results, and a comparison of results to fasciotomy. J Foot Ankle Surg 2002;41:166-72.

5. Steinmetz M. Treatment choices for plantar fasciitis. Am Fam Physician 1999;60:2504.

6. Seegenschmiedt MH, Keilholz L, Stecken A, Katalinic A, Sauer R. Radiotherapy of plantar heel spurs: indications, technique, clinical results at different dose concepts. Strahlenther Onkol 1996;172:37683.

7. Prichasuk S, Subhadrabandhu T. The relationship of pes planus and calcaneal spur to plantar heel pain. Clin Orthop Relat Res 1994:192-6.

8. Riepert T, Drechsler T, Urban R, Schild H, Mattern R. Häufigkeit, Altersabhängigkeit und Geschlechtsverteilung des Fersensporns. RöFo-Fortschritte auf dem Gebiet der Röntgenstrahlen und der bildgebenden Verfahren; 1995: (c) Georg Thieme Verlag Stuttgart· New York. p. 502-5.

9. Gill LH. Plantar Fasciitis: Diagnosis and Conservative Management. J Am Acad Orthop Surg 1997;5:109-17.

10. Brown C. A review of subcalcaneal heel pain and plantar fasciitis. Aust Fam Physician 1996;25:875$81 ; 84-5$.

11. MH MC. Handbuch der Orthopädie: Thieme Stuttgart; 1961.

12. Schreiber A. Entzündungen/Fersensporne: Thieme Stuttgart-New York.

13. SV SP. Zur Problematik des Kalkaneussporns. Z Rheumaforsch 1967;26 (9):353-63.

14. S. K. Der Fersenschmerz: Thieme, Stuttgart; 1956.

15. Cornwall MW, McPoil TG. Plantar fasciitis: etiology and treatment. J Orthop Sports Phys Ther 1999;29:756-60.

16. Furey JG. Plantar fasciitis. The painful heel syndrome. J Bone Joint Surg Am 1975;57:672-3.

17. Gudeman SD, Eisele SA, Heidt RS, Jr., Colosimo AJ, Stroupe AL. Treatment of plantar fasciitis by iontophoresis of $0.4 \%$ dexamethasone. A randomized, double-blind, placebo-controlled study. Am J Sports Med 1997;25:312-6.

18. Chandler TJ, Kibler WB. A biomechanical approach to the prevention, treatment and rehabilitation of plantar fasciitis. Sports Med 1993;15:344-52.

19. SG. M. Über den Kalkaneussporn. Röntgenpraxis (4) 1932:158-67.

20. DeMaio M, Paine R, Mangine RE, Drez D, Jr. Plantar fasciitis. Orthopedics 1993;16:1153-63.

21. Tisdel CL, Donley BG, Sferra JJ. Diagnosing and treating plantar fasciitis: a conservative approach to plantar heel pain. Cleve Clin J Med 1999;66:231-5.

22. Hammer DS, Rupp S, Kreutz A, Pape D, Kohn D, Seil R. Extracorporeal shockwave therapy (ESWT) in patients with chronic proximal plantar fasciitis. Foot Ankle Int 2002;23:309-13.

23. Krischek O, Rompe J-D, Herbsthofer B, Nafe B. Symptomatische niedrig-energetische Stoßwellentherapie bei Fersenschmerzen und radiologisch nachweisbarem plantaren Fersensporn. 
Zeitschrift für Orthopädie und ihre Grenzgebiete 1998;136:169-74.

24. Ogden JA, Alvarez RG, Marlow M. Shockwave therapy for chronic proximal plantar fasciitis: a metaanalysis. Foot Ankle Int 2002;23:301-8.

25. Perlick L BW GG. Hochenergetische Stoßwellenbehandlung des schmerzhaften Fersenspornes. Unfallchirurg 1998;101:914-8.

26. Schreiber H BG ZK. Strahlentherapie des schmerzhaften Fersenspornes: Diplodocus-Verlag, Altenberge.

27. Dailey JM. Differential diagnosis and treatment of heel pain. Clin Podiatr Med Surg 1991;8:153-66.

28. K T. Operative treatment of plantar fasciitis: J Med Assoc Thai 75

29. Oehler W. Hentschel B. Niedrigdosierte analgetische Radiotherapie von Arthrosen Ärztebl Thüring 2000;11:92-5.

30. Glatzel M, Bäsecke S, Krauß A, Fröhlich D. Radiotherapy of the painful plantar heel spur. Benig News 2001;2:18-9.

31. Mitrov G, Harbov I. Unsere Erfahrungen mit der Strahlentherapie von nichttumorartigen Erkrankungen. Radiobiol Radiother 1967;8:419.

32. Rowe CR, Sakellarides HT, Freeman PA, Sorbie C. Fractures of the os calcis: a long-term follow-up study of 146 patients. Jama 1963;184:920-3.

33. Seegenschmiedt MH, Katalinic A, Makoski H-B, Haase W, Gademann G, Hassenstein E. Strahlentherapie von gutartigen Erkrankungen: eine Bestandsaufnahme für Deutschland. Strahlentherapie und Onkologie 1999;175:541-7.

34. Seegenschmiedt MH, Keilholz L, Katalinic A, Stecken A, Sauer R. Heel spur: radiation therapy for refractory pain-results with three treatment concepts. Radiology 1996;200:271-6.

35. Arican M, Turhan Y, Karaduman ZO. A Rare Cause of Heel Pain: A Calcaneal Spur Fracture. J Am Podiatr Med Assoc 2019;109:172-3.

36. Behounek MI J, Skotak M, Behounek St J. [Open Heel Spur Surgery - Our Experience]. Acta Chir Orthop Traumatol Cech 2019;86:212-5.

37. Doruk Analan P. Role of radiotherapy in the management of heel spur. Eur J Orthop Surg Traumatol 2017;27:569.

38. Krol P, Franek A, Krol T, et al. Ground reaction force analysis for assessing the efficacy of focused and radial shockwaves in the treatment of symptomatic plantar heel spur. J Back Musculoskelet Rehabil 2021;34:279-87.

39. Luo JC, Lang BX. [Case-control study on the treatment of heel spur syndrome with modified stretching manipulation combined with needle Dao loosing]. Zhongguo Gu Shang 2018;31:504-9.

40. Notarnicola A, Maccagnano G, Moretti L, et al. Could the presence of heel spur be a prognostic factor for outcome of extracorporeal shock wave therapy for plantar fasciitis? J Biol Regul Homeost Agents 2019;33:1949-54. 
41. Prokein B, Holtmann H, Hautmann MG, et al. Radiotherapy of painful heel spur with two fractionation regimens : Results of a randomized multicenter trial after 48 weeks' follow-up. Strahlenther Onkol 2017;193:483-90.

42. Uysal B. Reply to letter to the editor about radiotherapy in the management of heel spur pain. Eur $\mathrm{J}$ Orthop Surg Traumatol 2018;28:757.

43. Zahnreich S, Rosler HP, Schwanbeck C, Karle H, Schmidberger H. Radiation-induced DNA doublestrand breaks in peripheral leukocytes and therapeutic response of heel spur patients treated by orthovoltage X-rays or a linear accelerator. Strahlenther Onkol 2020;196:1116-27.

44. Micke O, Seegenschmiedt M. German Cooperative Group on Radiotherapy for Benign Diseases. Radiotherapy in painful heel spurs (plantar fasciitis). Results of a national patterns of care study. Int J Radiat Oncol Biol Phys 2004;58:828-43.

45. Schaefer U, Micke O, Glashörster M, Rübe C, Prott F, Willich N. The radiotherapy treatment of painful calcaneal spurs. Strahlentherapie und Onkologie: Organ der Deutschen Rontgengesellschaft[et al] 1995;171:202-6.

46. Muecke R, Micke O, Reichl B, et al. Demographic, clinical and treatment related predictors for eventfree probability following low-dose radiotherapy for painful heel spurs - a retrospective multicenter study of 502 patients. Acta Oncol 2007;46:239-46.

47. R. A. Die Röntgenbehandlung der Epikondylitis und Kalkaneodynie. Fortschr Röntgenstr 32 1924:460.

48. Trott K, Parker R, Seed M. The effect of X-rays on the experimental arthritis in rats; Die Wirkung von Roentgenstrahlen auf die experimentelle Arthritis der Ratte. Strahlentherapie und Onkologie $1995 ; 171$.

49. Large M, Hehlgans S, Reichert S, et al. Study of the anti-inflammatory effects of low-dose radiation: The contribution of biphasic regulation of the antioxidative system in endothelial cells. Strahlenther Onkol 2015;191:742-9.

50. Basche S, Drescher W, Mohr K. Results of X-ray therapy of calcaneal spur. Radiobiologia Radiotherapia 1980;21:233-6.

51. Cocchi U. Erfolge und Mißerfolge bei Röntgenbestrahlung nichtkrebsiger Leiden. Strahlentherapie 1943;73:285.

52. Koeppen D, Bollmann G, Gademann G. Ein Beitrag zur Dosiswirkungsbeziehung bei der Röntgentherapie des Fersensporns. Strahlenther Onkol 2000;176:91.

53. Lederer K NU WK, et al. Perkutane Radiatio des schmerzhaften Fersensporns. MTA 1998;13:488-91.

54. Mantell BS. Radiotherapy for painful heel syndrome. Br Med J 1978;2:90-1.

55. Mustakallio S, Laitinen H. ÜBER DIE INSERTIONSSCHMERZEN, IHRE RÖNTGEN-DIAGNOSTIK UNDBEHANDLUNG. Acta Radiologica 1939:427-37.

56. P. P. La roentgentherapie des affections rhumatismales. Paris: Masson \& Cie 1957:142-3.

57. Schneider O, Stuckle CA, Bosch E, Gott C, Adamietz IA. Effectiveness and prognostic factors of radiotherapy for painful plantar heel spurs. Strahlenther Onkol 2004;180:502-9. 
58. Wieland C, Kuttig H. High-voltage therapy in arthroses and inflammations. Strahlentherapie 1965;127:44-8.

59. Zschache H. Ergebnisse der Röntgenschwachbestrahlung. Radiobiol Radiother 1972;13:181-6.

60. Lee AY, Akileswaran L, Tibbetts MD, Garg SJ, Van Gelder RN. Identification of torque teno virus in culture-negative endophthalmitis by representational deep DNA sequencing. Ophthalmology 2015;122:524-30.

61. Focosi D, Maggi F, Albani M, et al. Torquetenovirus viremia kinetics after autologous stem cell transplantation are predictable and may serve as a surrogate marker of functional immune reconstitution. J Clin Virol 2010;47:189-92.

62. Mustakallio S LH. Über die insertionsschmerz - ihre Diagnostik und Behandlung. . Acta Radiol 1939;20:427-37.

63. U. c. Erfolg und Mißerfolg bei Röntgenbestrahlung nichtkrebsiger Leiden. Strahlentherapie 1943;73:255-84.

64. Solodky ML, Galvez C, Russias B, et al. Lower detection rates of SARS-COV2 antibodies in cancer patients versus health care workers after symptomatic COVID-19. Ann Oncol 2020.

65. Wieland C KH. Hochvolttherapie bei Arthrosen und Entzündungen. Strahlentherapie 1965; 127: 44-8.

66. Mitrov G HI. Unsere Erfahrungen mit der Strahlenbehandlung von nichttumorartigen Erkrankungen. Radiobiol Radiother 8 (1967) 419-422

67. Chang TJ, Yang DM, Wang ML, et al. Genomic analysis and comparative multiple sequences of SARS-CoV2. J Chin Med Assoc 2020;83:537-43.

68. BS M. Radiotherapy for painful heel syndrome. Br Med J 2 (1978) 90-91.

69. Basche ST DW, Mohr K. Ergebnisse der Röntgenstrahlentherapie bei Fersensporn. Radiobiol Radiother 21 (1980) 233-236

70. Sautter-Biehl ML LH, Scheurig H, Heinze GH. Analgetische Bestrahlung degenerativ entzündlicher Skeletterkrankungen. Dtsch med Wschr 118 (1993) 493-498.

71. Schäfer U MO, Glashörster M et al. Strahlentherapeutische Behandlung des schmerzhaften Fersensporns. Strahlenther Onkol 171 (1995) 202-206

72. Seegenschmiedt MH KL, Katalinic A, Stecken A, Sauer R. Heel Spur: radiation therapy for refraktory pain-results with three traetment concepts. Radiology 200 (1996) 271-276

73. Lederer K NU, Walter K, et al. . Perkutane Radiatio des schmerzhaften Fersensporns. MTA 1998;13:488-91.

74. Oehler W HB. Niedrigdosierte analgetische Radiotherapie von Arthrosen. Ärzteblatt Thüringen 11 (2000) 92-95.

75. Koeppen D BG, Gademann G. Ein Beitrag zur Dosiswirkungsbeziehung bei der Röntgentherapie des Fersensporns. Strahlenther Onkol 176 Sondernr 1 (2000) 91

76. Schreiber H BG, Ziegler K. Strahlentherapie des schmerzhaften Fersenspornes. In : Seegenschmiedt MH, Makoski HB (Hrsg) : 10. Kolloquium Radioonkologie/Strahlentherapie. Radiotherapie von 
gutartigen Erkrankungen. Diplodocus-Verlag, Altenberge, 2000, S186-187.

77. Heyd R SG, Filipowicz I, Borowsky K, Martin T, Zamboglou N Radiotherapie in the managment of inflammatory calcaneal spurs: Results of a prospektiv study. In : Seegenschmiedt MH, Makoski HB (Hrsg) : 15.Kolloquim Radioonkologie/Strahlentherapie, Radiotherapie von gutartigen Erkrankungen. Diplodocus-Verlag, Altenberge, 2001, S173-183.

78. Glatzel M BS, Krauß A, Fröhlich D. Radiotherapy of painful plantar heel spur. Benig News 2 (2001) 1819.

79. Mücke R SK, Micke O, Berning D, Heyder R Radiotherapie of painful heel spurs -A retrospective study of 117 patients treated with 6-MeV-photons. Strahlenther Onkol 179 (2003) 774-778.

80. Schneider O SC, Bosch E, Gott C, Adamietz IA. Effectivness and prognostic factors of radiotherapy for painful plantar heel spurs. Strahlenther Onkol 180 (2004) 502-509.

81. Reinhard Heyd NT, Hanns Ackermann, Sandra J. Röddiger, Nikolaos Zamboglou. Funktionelle Ergebnisse nach Megavoltbestrahlung beim Fersensporn. Strahlenther Onkol (2006);182: 733-9 2006.

82. Heyd R TN, Ackermann H, Rödiger S, Zamboglou N. Radiation therapie for painful heel spurs. Stahlenther Onkol 183 (2007) 3-9.

83. Marcus Niewald MHS, Oliver Micke, Stefan Graeber, Ralf Muecke, Vera Schaefer, Christine Scheid, Jochen Fleckenstein, Norbert Licht, Christian Ruebe. Randomized, multicenter trial on the effect of radiation therapy on plantar fasciitis (painful Heel Spur) comparing a standard dose with a very low Dose: mature result after 12 months follow-up. . Int J Radiat Oncol Biol 2012:1-8 2012:1-8.

84. Mucke R, Schonekaes K, Micke O, Seegenschmiedt MH, Berning D, Heyder R. Low-dose radiotherapy for painful heel spur. Retrospective study of 117 patients. Strahlenther Onkol 2003;179:774-8.

85. Scherer E. Biologische Grundlagen und neuere Ergebnisse der Entzündungsbestrahlung und der funktionellen Röntgentherapie. Strahlentherapie 1955;97:349-61.

86. SMKLSAKAS R. Radiotherapie bei plantarem Fersensporn. Strahlenther Onkol 1996;172:376-83.

\section{Figures}


Figure 1

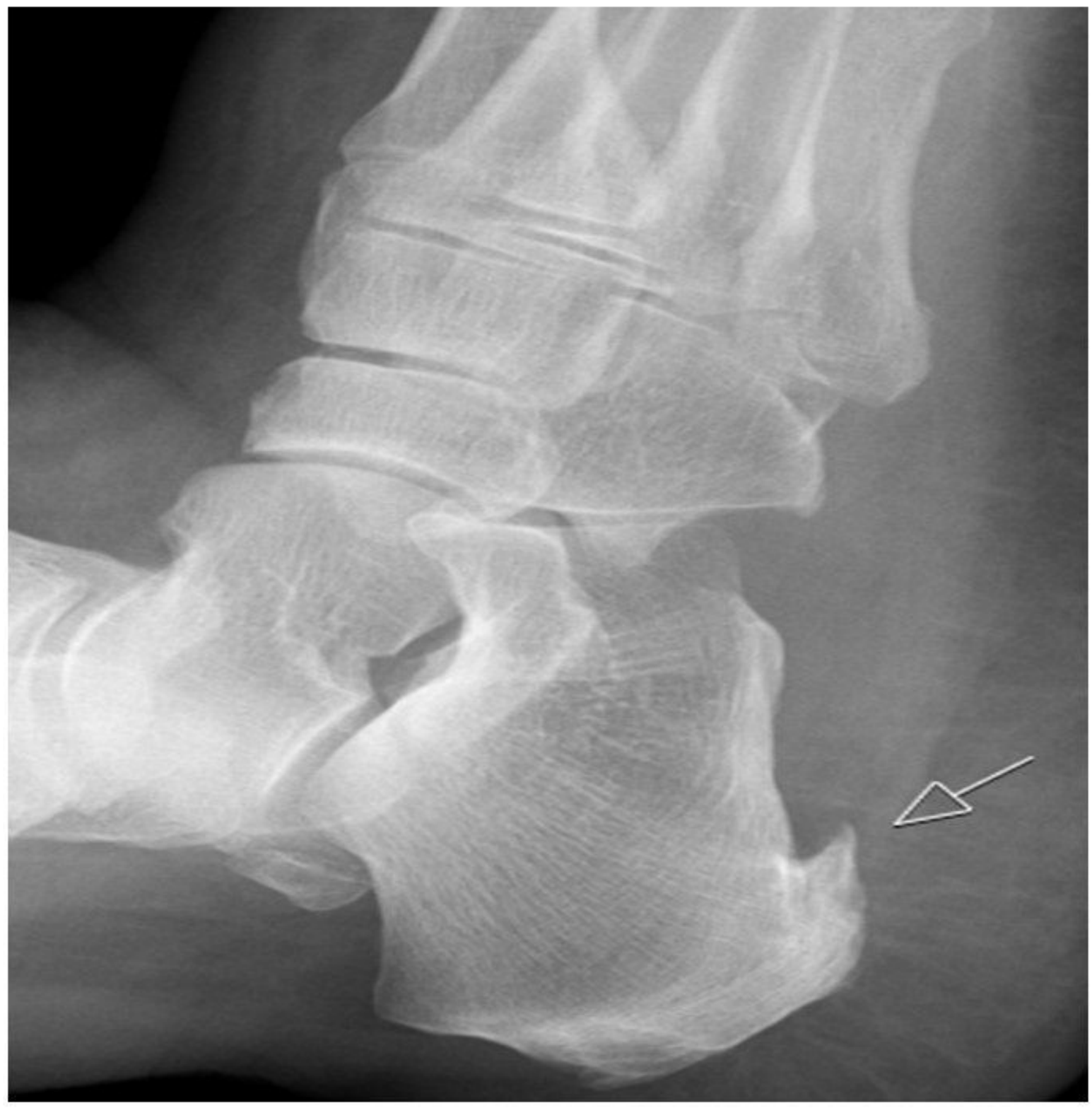

\section{Figure 1}

The x-ray of the calcaneus shows a hell spur with an inflammatory reaction surrounding the insertion of the inferior aponeurosis (arrow). 
pretherapeutical duration of pain $n=23$

size of irradiation field $n=8$

overall dose $n=17$

overall duration of treatment $n=38$

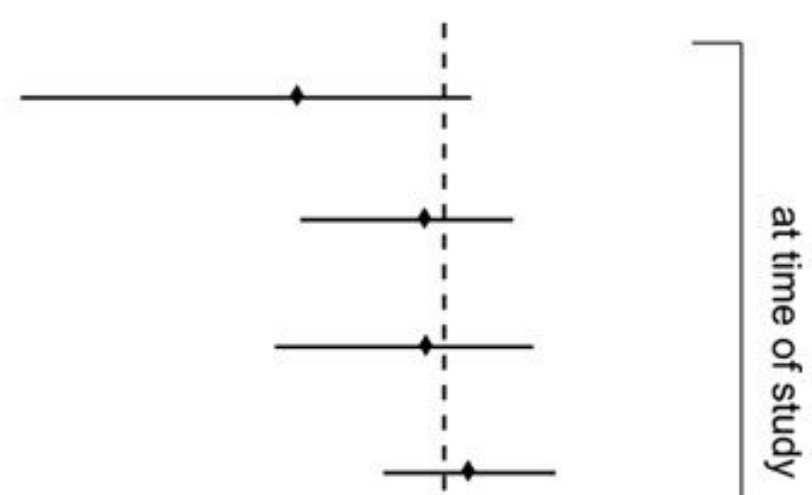

pretherapeutical duration of pain $n=12$

这

$$
\text { age } n=45
$$

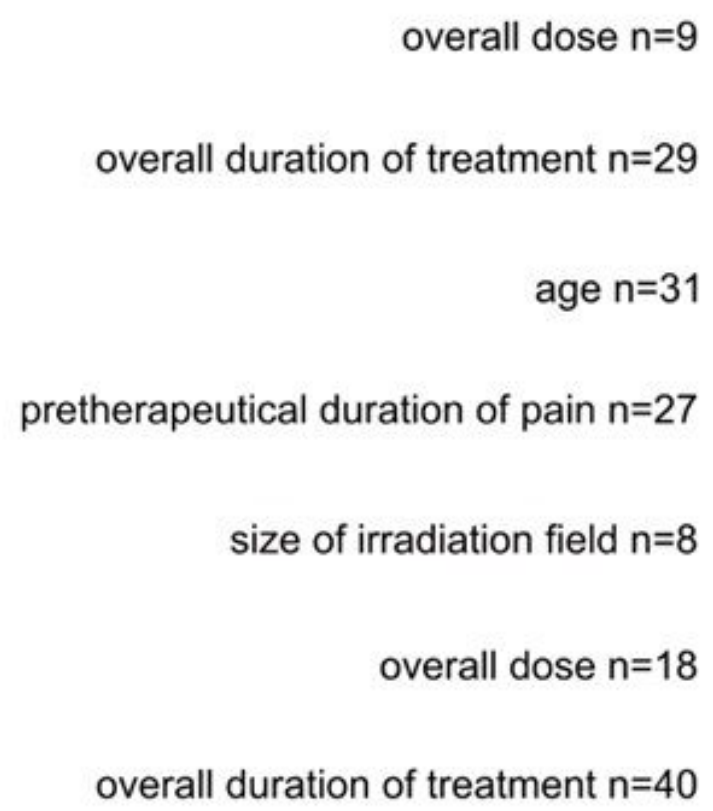

age $n=49$

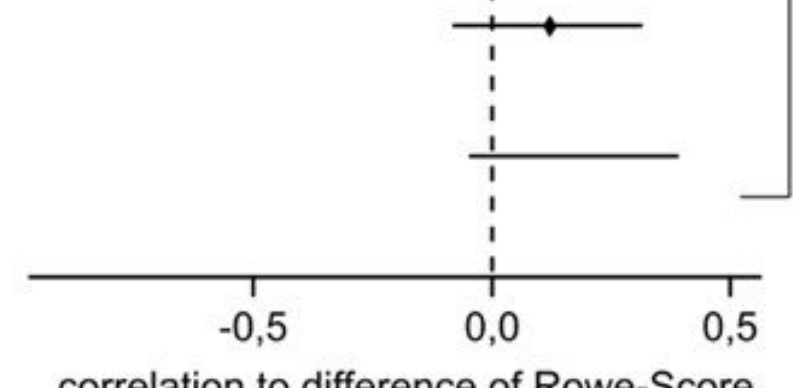

correlation to difference of Rowe-Score

\section{Figure 2}

Graphic depiction of the sum score before, after RT and at data collection. 


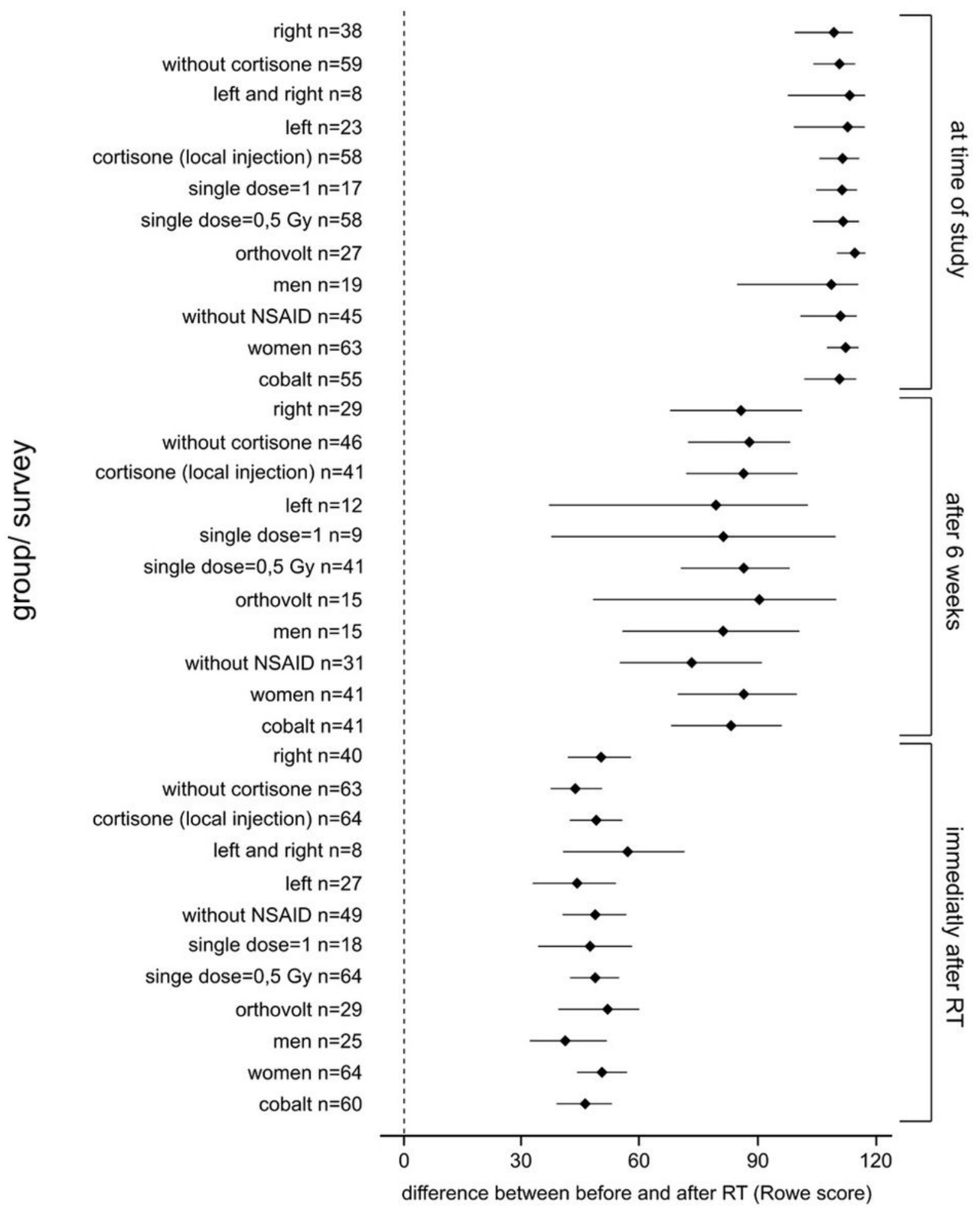

\section{Figure 3}

Bootstrap confidence interval of the therapeutic results for the correlation of age, total time of treatment, total dose, radiation field and the pretherapeutic time of pain to the difference of the Rowe-Scores before $\mathrm{RT}$, on the last day of RT, 6 weeks after RT and at time of data collection. 
graphic depiction of the sum score before, after RT and at data collection

Rowe sum score

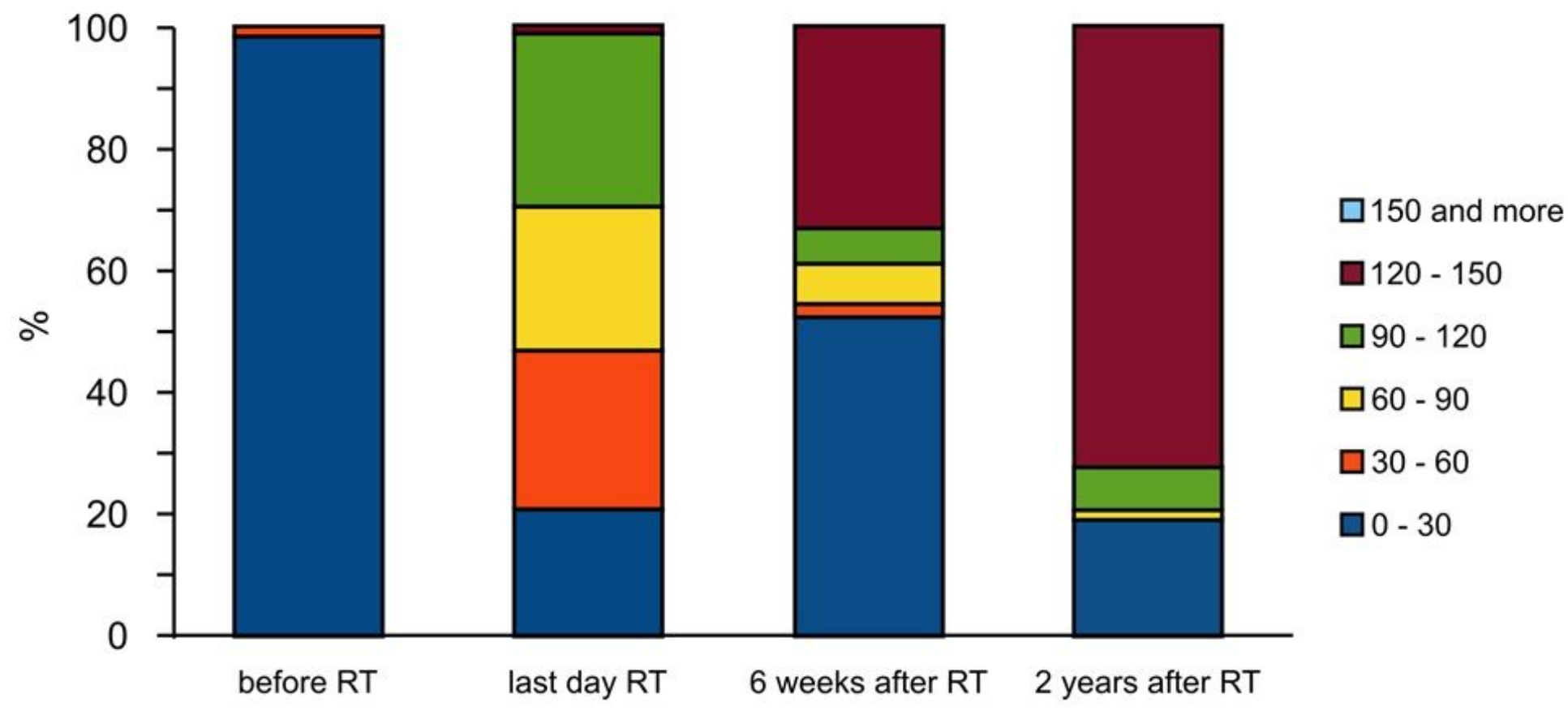

Figure 4

Summary of the bootstrap confidence intervals of radiation results using the modified Rowe-Scores on the last day of RT, 6 weeks after RT and at data collection. 